\title{
Diagnostic Power of Selected Cytokines, MMPs and TIMPs in Ovarian Cancer Patients - ROC Analysis
}

\author{
GRAŻYNA EWA BĘDKOWSKA ${ }^{1}$, BARBARA PISKÓR ${ }^{2}$, EWA GACUTA $^{3}$, MONIKA ZAJKOWSKA $^{4}$, \\ JOANNA OSADA ${ }^{1}$, MACIEJ SZMITKOWSKI ${ }^{4}$, MILENA DĄBROWSKA ${ }^{1}$ and SŁAWOMIR ŁAWICKI ${ }^{5}$ \\ ${ }^{1}$ Department of Haematological Diagnostics, Medical University of Białystok, Białystok, Poland; \\ ${ }^{2}$ Department of Esthetic Medicine, Medical University of Biatystok, Białystok, Poland; \\ ${ }^{3}$ Department of Perinatology Medical University of Białystok, Białystok, Poland; \\ ${ }^{4}$ Department of Biochemical Diagnostics, Medical University of Białystok, Białystok, Poland; \\ ${ }^{5}$ Department of Population Medicine and Civilization Diseases Prevention, \\ Medical University of Białystok, Białystok, Poland
}

\begin{abstract}
Background/Aim: The aim of the study was to identify new non-invasive ovarian cancer (OC) tumor markers. Materials and Methods: In postmenopausal ovarian cancer patients and in a control group (benign ovarian lesions and healthy subjects), preoperative plasma levels of cytokines, metalloproteinases and their tissue inhibitors were determined using ELISA while those of CA125 and HE4 by chemiluminescent microparticle immunoassay methods. Results: The diagnostic sensitivity (SE) value was the highest for HE4 and MMP-7 (78.0\%). The diagnostic specificity (SP) for M-CSF, VEGF and MMP-9 was 95.2\%, 95.2\% and $95.7 \%$, respectively. The highest positive predictive value (PPV) for M-CSF and MMP-9 was $~ 84.6 \%$ and negative predictive value (NPV) for MMP-7 and HE4 was $\sim 87.6 \%$. The biggest areas under the ROC curve were obtained for the combination of VEGF, MMP-7 or MMP-9 with HE4+CA125 (0.9130-0.9234), but not for CA125+HE4 (0.8260). Conclusion: Our research confirms the validity of combining classic markers with new markers to improve the diagnostic power of CA125 and HE4.
\end{abstract}

Ovarian cancer (OC) occurs at all ages and has a high mortality rate attributable to its occult development $(1,2)$. Recently published research has suggested that the majority of ovarian carcinomas originate from high-grade intraepithelial serous carcinomas in the fallopian tube which

Correspondence to: Grażyna Ewa Będkowska, Ph.D., Department of Haematological Diagnostics, Medical University Białystok, Waszyngtona 15A, 15-269 Białystok, Poland. Tel/Fax: +48 85 8318588, e-mail: grazyna.bedkowska@umb.edu.pl

Key Words: Cytokines, MMPs, TIMPs, epithelial ovarian cancer, tumor markers. then spread to the ovary (3). The best known and most widely used tumor markers in routine ovarian cancer diagnosis are CA125 (carbohydrate antigen 125) (4-7) and HE4 (human epididymis protein 4) $(5,8)$. Many researchers are working on detecting new markers useful for early diagnosis of epithelial ovarian cancer $(9,10)$. The overexpression and increased concentrations of metalloproteinases (MMPs), tissue inhibitors of metalloproteinases (TIMPs) or hematopoietic growth factors (HGFs) and cytokines have been observed in the course of various types of cancers $(6,7$, $11,12)$.

The aim of this study was to determine the diagnostic power, according to the analysis of area under the ROC curve, of selected cytokines (M-CSF- macrophage-colony stimulating factor; VEGF - vascular endothelial growth factor), MMPs (MMP-2 -metalloproteinase-2; MMP-7 metalloproteinase-7; MMP-9 - metalloproteinase-9), and TIMPs (TIMP-1 - tissue inhibitor of metalloproteinase-1; TIMP-2 - tissue inhibitor of metalloproteinase-2) separately and in combination with established tumor markers for the best cancer detection. To better reflect the female population, the control group included healthy women and women with benign ovarian lesions.

\section{Materials and Methods}

Patients. The groups studied are presented in Table I. A group of 140 postmenopausal women with epithelial ovarian cancer patients was analyzed. Clinical stages and histological classification were established based on the criteria of the International Federation of Gynecology and Obstetrics (FIGO) and the World Health Organization (WHO). Physical and blood examinations, ultrasound scanning and chest $\mathrm{X}$-rays were used in pretreatment staging procedures. Due to very high HE4 concentration levels, patients with renal failure were excluded. The patients had not received any therapy before blood sample collection. 
In the control group, 140 postmenopausal women [70 benign ovarian tumor (BOT) and 70 healthy volunteers] were included (Table I). The histopathology of the BOT group was established by tissue biopsy. Before blood collection the healthy women group was examined also by a gynecologist and an ultrasound examination was performed in every case. We excluded subjects with prior endometriosis or with renal failure.

Women with ovarian cancer or with benign lesions were patients of the Department of Gynecology, University Hospital in Białystok, Poland, in the years 2009-2014. All research participants had given their permission to be part of the study. The local Ethics Committee of the Medical University in Białystok, approved the study: R-I002/314/2009; R-I-002/262/2010 and R-I-002/239/2014.

Biochemical analyses. Plasma samples were obtained following centrifugation (1000 rpm/15 min.) of venous blood collected into heparin sodium tubes and stored at $-85^{\circ} \mathrm{C}$. Duplicate samples were measured for each patient with enzyme-linked immunosorbent assay (ELISA) (Quantikine Human Immunoassay, R\&D systems) for cytokines, metalloproteinases (MMPs) and tissue inhibitors of metalloproteinase (TIMPs). The assay showed no significant crossreactivity with other human cytokines, metalloproteinases and tissue inhibitors of metalloproteinases.

The concentrations of comparable markers were assayed by chemiluminescent microparticle immunoassay (CMIA) (Abbott, Chicago, IL, USA).

The intra-assay coefficient of variation $(\mathrm{CV} \%)$ of M-CSF is reported to be $3.4 \%$ at a mean concentration of $227 \mathrm{pg} / \mathrm{ml}, \mathrm{SD}=7.7$; of VEGF, $4.5 \%$ at a mean concentration of $235 \mathrm{pg} / \mathrm{ml}, \mathrm{SD}=10.6$; of MMP-2, 3.8\% at a mean concentration of $11.2 \mathrm{ng} / \mathrm{ml}, \mathrm{SD}=0.420$; of MMP-7, $3.7 \%$ at a mean concentration of $4.58 \mathrm{ng} / \mathrm{ml}, \mathrm{SD}=0.168$; of MMP-9, 2.9\% at a mean concentration of $11.0 \mathrm{ng} / \mathrm{ml}, \mathrm{SD}=0.316$; of TIMP-1, 5.0\% at a mean concentration of $6.95 \mathrm{ng} / \mathrm{ml}, \mathrm{SD}=0.35$; and of TIMP-2, $3.4 \%$ at a mean concentration of $3.45 \mathrm{ng} / \mathrm{ml}, \mathrm{SD}=0.116$. The intra-assay $\mathrm{CV}$ for CA125 is reported to be $2.4 \%$ at a mean concentration of $43.5 \mathrm{U} / \mathrm{ml}, \mathrm{SD}=1.1$ and that of HE4 $3.7 \%$ at a mean concentration of $39.0 \mathrm{pmol} / 1, \mathrm{SD}=1.4$.

The inter-assay coefficient of variation $(\mathrm{CV} \%)$ of $\mathrm{M}-\mathrm{CSF}$ is reported to be $3.1 \%$ at a mean concentration of $232 \mathrm{pg} / \mathrm{ml}$, $\mathrm{SD}=7.3$; of VEGF, $7.0 \%$ at a mean concentration of $250 \mathrm{pg} / \mathrm{ml}$, $\mathrm{SD}=17.4$; of MMP-2, $6.6 \%$ at a mean concentration of $11.1 \mathrm{ng} / \mathrm{ml}$, $\mathrm{SD}=0.738$; of MMP-7, $4.1 \%$ at a mean concentration of 4.82 $\mathrm{ng} / \mathrm{ml}, \mathrm{SD}=0.198$; of MMP-9, 6.9\% at a mean concentration of $12.2 \mathrm{ng} / \mathrm{ml}, \mathrm{SD}=0.845$; of TIMP-1, $4.9 \%$ at a mean concentration of $6.90 \mathrm{ng} / \mathrm{ml}, \mathrm{SD}=0.34$; and of TIMP-2, $5.7 \%$ at a mean concentration of $3.45 \mathrm{ng} / \mathrm{ml}, \mathrm{SD}=0.197$. The inter-assay $\mathrm{CV}$ for CA125 is reported to be $3.9 \%$ at a mean concentration of 43.5 $\mathrm{U} / \mathrm{ml}, \mathrm{SD}=1.7$, and that of HE4 $2.8 \%$ at a mean concentration of $39.0 \mathrm{pmol} / 1, \mathrm{SD}=1.1$.

Statistical analysis. We performed statistical analysis using the STATISTICA 12.0 PL program. The diagnostic power of all studied markers was compared by assessing the significance of differences between the areas under their ROC curves $(p<0.05)$, (the GraphRoc Program for Windows).

The cut-off values were calculated by Youden's index and were as follows: M-CSF $1004.9 \mathrm{pg} / \mathrm{ml}$; VEGF $402.6 \mathrm{pg} / \mathrm{ml}$; MMP-2 $194.8 \mathrm{ng} / \mathrm{ml}$; MMP-7 $3.9 \mathrm{ng} / \mathrm{ml}$; MMP-9 $519.8 \mathrm{ng} / \mathrm{ml}$; TIMP-1 $170.0 \mathrm{ng} / \mathrm{ml}$; TIMP-2 $49.4 \mathrm{ng} / \mathrm{ml}$; HE4 $72.3 \mathrm{pmol} / 1$ and CA125 $81.3 \mathrm{U} / \mathrm{ml}$.

\section{Results}

Tables II and III present the sensitivity (SE), specificity (SP), positive (PPV) and negative (NPV) predictive values of the tested parameters. The SE value in the ovarian cancer group was the highest for HE4 (78.0\%) and MMP-7 (78.0\%). The diagnostic SP was the highest for M-CSF, VEGF and MMP9 (95.2\%; $95.2 \%, 95.7 \%$ respectively) and was higher than that for CA125 (91.0\%) and HE4 (82.2\%). We indicated also the highest PPV value for M-CSF (84.5\%) and MMP-9 $(84.6 \%)$ and the highest NPV value for MMP-7 and HE4 $(87.6 \%$ and $87.4 \%$ ) (Table II). The combined analysis of the investigated parameters resulted in a high increase in the SE value and the maximum ranges were obtained for the combination of MMP-7, MMP-9 or M-CSF with both conventional tumor markers (95.0\%; 94.0\%; 93.0\%, respectively). The SP and PPV values dropped slightly during the combined analysis (Table III). In the OC cancer group the NPV values were the highest for the combination of: VEGF+CA125 (97.8\%), MMP-7+CA125+HE4 (96.2\%) and $\mathrm{M}-\mathrm{CSF}+\mathrm{CA} 125+\mathrm{HE} 4$ (95.2\%). Interestingly, the diagnostic criteria demonstrated for the combined CA125 and HE4 analysis reached lower values: SE-89.0\%, SP87.0\%, PPV-68.5\% and NPV-92.9\% (Table III).

The ROC (receiver-operating characteristics) is a commonly used method for comparing the diagnostic power of laboratory tests. The AUCs (area under the ROC curve) of every biomarker compared with the remaining group were significantly higher compared to AUC $=0.5$ (with exception of MMP-2 and TIMP-2) (Table IV). HE4 (0.8647), CA125 (0.8301) and MMP-7 (0.8260) areas under the ROC curve were the largest in the OC group (Table IV; Figure 1). The combination of biomarkers studied resulted in a further increase in the area under the ROC curve (Table IV, Figures 2-4). Especially for the combination of VEGF, MMP-7 or MMP-9 with HE4+CA125, increased to the value: 0.91300.9234 (Table IV). It should be emphasized that the areas under the ROC for the tested biomarkers in combination with HE4 or CA125 were larger than those for the CA125 and HE4 combination (0.8260) (Table III; Figure 5).

\section{Discussion}

In this study, the analysis of the area under the ROC curve was utilized to determine the diagnostics usefulness of selected cytokines, metalloproteinases and tissue inhibitors of metalloproteinases separately and in combination with accepted markers of ovarian cancer. The diagnostic performance of researched markers in discriminating OC from the control group comprised of BOT and healthy subjects showed the best results for comparative markers. Moreover, HE4 (0.8647) was better in discriminating between the aforementioned groups than CA125 (0.8301). 
Table I. Presentation of OC patients and control group (BOT and healthy subjects).

\begin{tabular}{|c|c|c|}
\hline & Study group & $\begin{array}{c}\text { Number of } \\
\text { patients }\end{array}$ \\
\hline & Epithelial ovarian cancer patients & $140(100 \%)$ \\
\hline & - median age (range) & $60(47-87)$ \\
\hline & - sub-type serous epithelial & $72(52 \%)$ \\
\hline & - median age (range) & $60(47-82)$ \\
\hline & - sub-type endometrioid epithelial & $68(48 \%)$ \\
\hline & - median age (range) & $60(49-87)$ \\
\hline \multirow[t]{13}{*}{ Tested group } & Tumor stage & \\
\hline & $\mathrm{IA}-\mathrm{T}_{1 \mathrm{a}} \mathrm{N}_{0} \mathrm{M}_{0}$ & $10(7.1 \%)$ \\
\hline & IB- $\mathrm{T}_{1 \mathrm{~b}} \mathrm{~N}_{0} \mathrm{M}_{0}$ & $12(8.6 \%)$ \\
\hline & IC- $\mathrm{T}_{1 \mathrm{c}} \mathrm{N}_{0} \mathrm{M}_{0}$ & $14(10 \%)$ \\
\hline & IIA- $\mathrm{T}_{2 \mathrm{a}} \mathrm{N}_{0} \mathrm{M}_{0}$ & $11(7.8 \%)$ \\
\hline & IIB- $\mathrm{T}_{2 \mathrm{~b}} \mathrm{~N}_{0} \mathrm{M}_{0}$ & $14(10 \%)$ \\
\hline & IIC- $\mathrm{T}_{2 \mathrm{c}} \mathrm{N}_{0} \mathrm{M}_{0}$ & $10(7.1 \%)$ \\
\hline & IIIA- ${ }_{3 a} \mathrm{~N}_{0} \mathrm{M}_{0}$ & $13(9.4 \%)$ \\
\hline & IIIB- $\mathrm{T}_{3 \mathrm{~b}} \mathrm{~N}_{0} \mathrm{M}_{0}$ & $12(8.6 \%)$ \\
\hline & IIIC- $\mathrm{T}_{3 \mathrm{c}} \mathrm{N}_{0} \mathrm{M}_{0}$ & $12(8.6 \%)$ \\
\hline & IV(metastases) & $32(22.8 \%)$ \\
\hline & Menopausal status: & $140(100 \%)$ \\
\hline & - postmenopausal & \\
\hline \multirow[t]{10}{*}{ Control group } & Benign ovarian tumor patients & $70(100 \%)$ \\
\hline & - type cystis serous & $36(51 \%)$ \\
\hline & - type cystis endometriosis & $34(49 \%)$ \\
\hline & Median age (range) & $58(48-72)$ \\
\hline & Menopausal status: & \\
\hline & - postmenopausal & $70(100 \%)$ \\
\hline & Healthy subjects & $70(100 \%)$ \\
\hline & Median age (range) & $57(47-66)$ \\
\hline & Menopausal status: & \\
\hline & - postmenopausal & $70(100 \%)$ \\
\hline
\end{tabular}

Our data are in accordance with (13-15) or different from (16-18) the results from other studies. The differences of the results between the studies might be due to differences in the disease stages and histologic types of ovarian cancer group and the composition of control groups enrolled in each study. The MMP-7 AUC value (0.8260) was slightly lower than that of CA125 and it was the best result among all tested cytokines, metalloproteinases and their tissue inhibitors. These results correspond to our previous study (19) though the ROC curve was plotted for the healthy women group $v s$. malignant cases group. The combination of CA125+HE4 with MMP-7, MMP-9 or VEGF resulted in the best diagnostic power with the highest AUC value, up to 0.9234 . Comparable results were obtained regarding: VEGF, MMP9 or MMP-7 in the ovarian $(19-22)$ breast $(23,24)$ or gastric cancer (25). Interestingly, the AUC value was smaller during the combined analysis of both commonly used tumor markers (0.8260). The work of Jacob et al. (12) in a group of postmenopausal women confirmed our observations. MCSF, MMP-2, TIMP-1 and TIMP-2 separately showed
Table II. The diagnostic criteria of tested parameters in epithelial ovarian cancer patients.

\begin{tabular}{|c|c|c|}
\hline Tested parameters & $\begin{array}{l}\text { Diagnostic } \\
\text { criteria }(\%)\end{array}$ & Total group \\
\hline \multirow[t]{4}{*}{ M-CSF } & SE & 49.0 \\
\hline & SP & 95.2 \\
\hline & PPV & 84.5 \\
\hline & NPV & 77.6 \\
\hline \multirow[t]{4}{*}{ VEGF } & SE & 45.0 \\
\hline & SP & 95.2 \\
\hline & PPV & 83.3 \\
\hline & NPV & 76.3 \\
\hline \multirow[t]{4}{*}{ MMP-2 } & SE & 44.0 \\
\hline & SP & 68.8 \\
\hline & PPV & 43.1 \\
\hline & NPV & 69.6 \\
\hline \multirow[t]{4}{*}{ MMP-7 } & $\mathrm{SE}$ & 78.0 \\
\hline & SP & 83.8 \\
\hline & PPV & 72.2 \\
\hline & NPV & 87.6 \\
\hline \multirow[t]{4}{*}{ MMP-9 } & SE & 44.0 \\
\hline & SP & 95.7 \\
\hline & PPV & 84.6 \\
\hline & NPV & 76.1 \\
\hline \multirow[t]{4}{*}{ TIMP-1 } & $\mathrm{SE}$ & 52.0 \\
\hline & SP & 82.2 \\
\hline & PPV & 61.2 \\
\hline & NPV & 78.5 \\
\hline \multirow[t]{4}{*}{ TIMP-2 } & SE & 21.0 \\
\hline & SP & 90.2 \\
\hline & PPV & 70.0 \\
\hline & NPV & 69.1 \\
\hline \multirow[t]{4}{*}{ CA125 } & SE & 63.0 \\
\hline & SP & 91.0 \\
\hline & PPV & 79.7 \\
\hline & NPV & 82.1 \\
\hline \multirow[t]{4}{*}{ HE4 } & SE & 78.0 \\
\hline & SP & 82.2 \\
\hline & PPV & 70.2 \\
\hline & NPV & 87.4 \\
\hline
\end{tabular}

SE: Sensitivity; SP: specificity; PPV: positive predictive value; NPV: negative predictive value.

limited diagnostic power in discriminating between the groups mentioned above. In contrast, other investigators found that increased serum levels of TIMP-1 and the ratio of TIMP-1 to MMP-2 as well as the ratio of TIMP-1 to the complex: MMP-2-TIMP-2 are useful in discriminating between malignant ovarian tumors and ovarian tumors of low malignant potential (26). However, the tested group was composed mainly of serous and mucinous malignant ovarian tumors and was far smaller (61 patients) (26). Our data are also in opposition to the studies of other researchers, who compared urinary TIMP-1 and MMP-2 levels in patients with pancreatic malignancies (27). Our present observations about the diagnostic power of M-CSF are in disagreement 
Table III. The diagnostic criteria of tested parameters in combined analysis with CA125 and/or HE4.

\begin{tabular}{|c|c|c|c|c|c|c|c|c|}
\hline $\begin{array}{l}\text { Tested } \\
\text { parameters }\end{array}$ & $\begin{array}{l}\text { Diagnostic } \\
\text { criteria }(\%)\end{array}$ & $\begin{array}{l}\text { Total } \\
\text { group }\end{array}$ & $\begin{array}{c}\text { Tested } \\
\text { parameters }\end{array}$ & $\begin{array}{l}\text { Diagnostic } \\
\text { criteria (\%) }\end{array}$ & $\begin{array}{l}\text { Total } \\
\text { group }\end{array}$ & $\begin{array}{c}\text { Tested } \\
\text { parameters }\end{array}$ & $\begin{array}{l}\text { Diagnostic } \\
\text { criteria }(\%)\end{array}$ & $\begin{array}{l}\text { Total } \\
\text { group }\end{array}$ \\
\hline M-CSF & SE & 78.0 & M-CSF & SE & 88.0 & M-CSF & SE & 93.0 \\
\hline+ & $\mathrm{SP}$ & 87.1 & + & SP & 79.0 & + & SP & 74.7 \\
\hline CA125 & $\begin{array}{l}\text { PPV } \\
\text { NPV }\end{array}$ & $\begin{array}{l}76.5 \\
88.0\end{array}$ & HE4 & $\begin{array}{l}\text { PPV } \\
\text { NPV }\end{array}$ & $\begin{array}{l}69.3 \\
92.4\end{array}$ & $\begin{array}{c}\text { CA125 } \\
+ \\
\text { HE4 }\end{array}$ & $\begin{array}{l}\text { PPV } \\
\text { NPV }\end{array}$ & $\begin{array}{l}66.4 \\
95.2\end{array}$ \\
\hline VEGF & SE & 74.0 & VEGF & SE & 85.0 & VEGF & SE & 91.0 \\
\hline+ & SP & 88.2 & + & SP & 79.0 & + & SP & 75.2 \\
\hline CA125 & $\begin{array}{l}\text { PPV } \\
\text { NPV }\end{array}$ & $\begin{array}{l}77.1 \\
97.8\end{array}$ & HE4 & $\begin{array}{l}\text { PPV } \\
\text { NPV }\end{array}$ & $\begin{array}{l}68.5 \\
90.7\end{array}$ & $\begin{array}{c}\text { CA125 } \\
+ \\
\text { HE4 }\end{array}$ & $\begin{array}{l}\text { PPV } \\
\text { NPV }\end{array}$ & $\begin{array}{l}66.4 \\
93.9\end{array}$ \\
\hline MMP-2 & SE & 81.0 & MMP-2 & SE & 84.0 & MMP-2 & SE & 92.0 \\
\hline+ & SP & 62.9 & + & SP & 58.1 & + & SP & 55.4 \\
\hline CA125 & $\begin{array}{l}\text { PPV } \\
\text { NPV }\end{array}$ & $\begin{array}{l}54.0 \\
86.0\end{array}$ & HE4 & $\begin{array}{l}\text { PPV } \\
\text { NPV }\end{array}$ & $\begin{array}{l}53.3 \\
90.7\end{array}$ & $\begin{array}{c}\text { CA125 } \\
+ \\
\text { HE4 }\end{array}$ & $\begin{array}{l}\text { PPV } \\
\text { NPV }\end{array}$ & $\begin{array}{l}53.4 \\
93.4\end{array}$ \\
\hline $\begin{array}{l}\text { MMP-7 } \\
+ \\
\text { CA125 }\end{array}$ & $\begin{array}{c}\text { SE } \\
\text { SP } \\
\text { PPV } \\
\text { NPV }\end{array}$ & $\begin{array}{l}93.0 \\
76.8 \\
68.4 \\
95.3\end{array}$ & $\begin{array}{c}\text { MMP-7 } \\
+ \\
\text { HE4 }\end{array}$ & $\begin{array}{c}\text { SE } \\
\text { SP } \\
\text { PPV } \\
\text { NPV }\end{array}$ & $\begin{array}{l}89.0 \\
71.5 \\
62.7 \\
92.4\end{array}$ & $\begin{array}{c}\text { MMP-7 } \\
+ \\
\text { CA125 } \\
+ \\
\text { HE4 }\end{array}$ & $\begin{array}{c}\text { SE } \\
\text { SP } \\
\text { PPV } \\
\text { NPV }\end{array}$ & $\begin{array}{l}95.0 \\
67.7 \\
61.3 \\
96.2\end{array}$ \\
\hline $\begin{array}{l}\text { MMP-9 } \\
+ \\
\text { CA125 }\end{array}$ & $\begin{array}{c}\text { SE } \\
\text { SP } \\
\text { PPV } \\
\text { NPV }\end{array}$ & $\begin{array}{l}75.0 \\
87.6 \\
76.3 \\
86.7\end{array}$ & $\begin{array}{c}\text { MMP-9 } \\
+ \\
\text { HE4 }\end{array}$ & $\begin{array}{c}\text { SE } \\
\text { SP } \\
\text { PPV } \\
\text { NPV }\end{array}$ & $\begin{array}{l}90.0 \\
78.5 \\
69.2 \\
93.6\end{array}$ & $\begin{array}{c}\text { MMP-9 } \\
+ \\
\text { CA125 } \\
+ \\
\text { HE4 }\end{array}$ & $\begin{array}{c}\text { SE } \\
\text { SP } \\
\text { PPV } \\
\text { NPV }\end{array}$ & $\begin{array}{l}94.0 \\
74.7 \\
66.6 \\
95.8\end{array}$ \\
\hline $\begin{array}{l}\text { TIMP-1 } \\
+ \\
\text { CA125 }\end{array}$ & $\begin{array}{c}\text { SE } \\
\text { SP } \\
\text { PPV } \\
\text { NPV }\end{array}$ & $\begin{array}{l}76.0 \\
74.2 \\
61.3 \\
85.2\end{array}$ & $\begin{array}{c}\text { TIMP-1 } \\
+ \\
\text { HE4 }\end{array}$ & $\begin{array}{c}\text { SE } \\
\text { SP } \\
\text { PPV } \\
\text { NPV }\end{array}$ & $\begin{array}{l}85.0 \\
70.4 \\
60.7 \\
89.7\end{array}$ & $\begin{array}{c}\text { TIMP-1 } \\
+ \\
\text { CA125 } \\
+ \\
\text { HE4 }\end{array}$ & $\begin{array}{c}\text { SE } \\
\text { SP } \\
\text { PPV } \\
\text { NPV }\end{array}$ & $\begin{array}{l}91.0 \\
65.6 \\
58.7 \\
93.1\end{array}$ \\
\hline $\begin{array}{l}\text { TIMP-2 } \\
+ \\
\text { CA125 }\end{array}$ & $\begin{array}{c}\text { SE } \\
\text { SP } \\
\text { PPV } \\
\text { NPV }\end{array}$ & $\begin{array}{l}71.0 \\
76.3 \\
74.7 \\
83.0\end{array}$ & $\begin{array}{c}\text { TIMP-2 } \\
+ \\
\text { HE4 }\end{array}$ & $\begin{array}{c}\text { SE } \\
\text { SP } \\
\text { PPV } \\
\text { NPV }\end{array}$ & $\begin{array}{l}83.0 \\
68.8 \\
67.7 \\
88.9\end{array}$ & $\begin{array}{c}\text { TIMP-2 } \\
+ \\
\text { CA125 } \\
+ \\
\text { HE4 }\end{array}$ & $\begin{array}{c}\text { SE } \\
\text { SP } \\
\text { PPV } \\
\text { NPV }\end{array}$ & $\begin{array}{l}91.0 \\
64.5 \\
65.5 \\
93.0\end{array}$ \\
\hline $\begin{array}{l}\text { CA125 } \\
+ \\
\text { HE4 }\end{array}$ & $\begin{array}{c}\text { SE } \\
\text { SP } \\
\text { PPV } \\
\text { NPV }\end{array}$ & $\begin{array}{l}89.0 \\
87.0 \\
68.5 \\
92.9\end{array}$ & & & & & & \\
\hline
\end{tabular}

SE: Sensitivity; SP: specificity; PPV: positive predictive value; NPV: negative predictive value.

with the results of our previous studies in ovarian (AUC=0.8562-0.8864) $(6,28)$, endometrial $(\mathrm{AUC}=0.794)$ (29) or breast cancer (AUC $=0.769-0.801)(24,30-32)$. These data were obtained after statistical analysis of the ROC curve between the group of women with cancer disease versus healthy individuals. We believe that the composition of the presented control group reflects better the current population of women and makes our analysis more reliable. According to calculated by Youden's index cut-off for selected biomarkers, HE4 and MMP-7 presented the highest and equal values of diagnostic SE (78\%). Furthermore, a maximum increase in the diagnostic SE was obtained for the combination of M-CSF, MMP-7 or MMP-9 with both ovarian tumor markers to $93-95 \%$ as compared with the use of both CA125 and HE4 together. Our data are similar to the published results of other investigators who found that the combination of CA125, MMP-7, CCL11 (CC chemokine 11) and CCL18 (CC chemokine 18) improves the diagnostic SE value in the early stages of ovarian cancer (94\%) (33). Zhang et al. $(34,35)$ postulated the usefulness of the combined detection of MMP-9, Hpa (heparanase) and CL (cathepsin L) for patients' clinical evaluation and determination of the extent of OC metastasis before surgery. The conclusion about $\mathrm{M}-\mathrm{CSF}$ is also in line with our previous studies, in which 
Będkowska et al: ROC Analysis of Selected Biomarkers in OC

Table IV. The diagnostic criteria of the ROC curve for tested parameters in epithelial ovarian cancer patients' group.

\begin{tabular}{|c|c|c|c|c|c|}
\hline Tested parameters & AUC & SE & 95\%CI (AUC) & $p$-Value $(\mathrm{AUC}=0.5)$ & Accuracy $(\%)$ \\
\hline M-CSF & 0.6898 & 0.0347 & $0.622-0.758$ & $<0.001$ & 79.0 \\
\hline $\mathrm{M}-\mathrm{CSF}+\mathrm{CA} 125$ & 0.8289 & 0.0270 & $0.776-0.882$ & $<0.001$ & 80.4 \\
\hline $\mathrm{M}-\mathrm{CSF}+\mathrm{HE} 4$ & 0.8852 & 0.0230 & $0.840-0.930$ & $<0.001$ & 84.6 \\
\hline $\mathrm{M}-\mathrm{CSF}+\mathrm{CA} 125+\mathrm{HE} 4$ & 0.9093 & 0.0212 & $0.866-0.949$ & $<0.001$ & 88.1 \\
\hline VEGF & 0.6812 & 0.0343 & $0.614-0.748$ & $<0.001$ & 77.2 \\
\hline VEGF+CA125 & 0.8375 & 0.0263 & $0.786-0.889$ & $<0.001$ & 80.1 \\
\hline VEGF+HE4 & 0.8931 & 0.0205 & $0.853-0.933$ & $<0.001$ & 85.7 \\
\hline VEGF+CA125+HE4 & 0.9139 & 0.0190 & $0.877-0.951$ & $<0.001$ & 87.1 \\
\hline MMP-2 & 0.5471 & 0.0372 & $0.474-0.620$ & 0.2055 & 59.8 \\
\hline MMP-2+CA125 & 0.8202 & 0.0300 & $0.761-0.879$ & $<0.001$ & 83.2 \\
\hline MMP-2+HE4 & 0.8697 & 0.0244 & $0.822-0.918$ & $<0.001$ & 85.3 \\
\hline MMP-2+CA $125+\mathrm{HE} 4$ & 0.9077 & 0.0198 & $0.870-0.948$ & $<0.001$ & 87.1 \\
\hline MMP-7 & 0.8260 & 0.0296 & $0.768-0.884$ & $<0.001$ & 81.5 \\
\hline MMP-7+CA125 & 0.8971 & 0.0223 & $0.853-0.941$ & $<0.001$ & 86.7 \\
\hline MMP-7+HE4 & 0.8981 & 0.0232 & $0.853-0.944$ & $<0.001$ & 87.1 \\
\hline MMP-7+CA125+HE4 & 0.9234 & 0.0196 & $0.885-0.962$ & $<0.001$ & 86.4 \\
\hline MMP-9 & 0.6477 & 0.0370 & $0.575-0.720$ & 0.0001 & 77.6 \\
\hline MMP-9+CA125 & 0.8116 & 0.0296 & $0.754-0.870$ & $<0.001$ & 81.1 \\
\hline MMP-9+HE4 & 0.8923 & 0.0215 & $0.850-0.934$ & $<0.001$ & 83.9 \\
\hline MMP-9+CA125+HE4 & 0.9130 & 0.0197 & $0.874-0.952$ & $<0.001$ & 86.0 \\
\hline TIMP-1 & 0.6819 & 0.0362 & $0.611-0.753$ & $<0.001$ & 71.3 \\
\hline TIMP-1+CA125 & 0.8183 & 0.0304 & $0.759-0.878$ & $<0.001$ & 82.2 \\
\hline TIMP-1+HE4 & 0.8794 & 0.0244 & $0.832-0.927$ & $<0.001$ & 82.5 \\
\hline TIMP-1+CA125+HE4 & 0.9080 & 0.0212 & $0.866-0.950$ & $<0.001$ & 86.0 \\
\hline TIMP-2 & 0.5312 & 0.0405 & $0.452-0.611$ & 0.4406 & 69.2 \\
\hline TIMP-2+CA125 & 0.8030 & 0.0318 & $0.741-0.865$ & $<0.001$ & 81.1 \\
\hline TIMP-2+HE4 & 0.8630 & 0.0275 & $0.809-0.917$ & $<0.001$ & 86.4 \\
\hline TIMP-2+CA125+HE4 & 0.9078 & 0.0216 & $0.866-0.950$ & $<0.001$ & 88.8 \\
\hline CA125 & 0.8301 & 0.0262 & $0.779-0.881$ & $<0.001$ & 81.5 \\
\hline HE4 & 0.8647 & 0.0259 & $0.814-0.915$ & $<0.001$ & 81.1 \\
\hline CA125+HE4 & 0.8260 & 0.0200 & $0.787-0.866$ & $<0.001$ & 81.3 \\
\hline
\end{tabular}

SE: Sensitivity; CI: confidence intervals of area under the curve (AUC). $p$-Value statistically significant when comparing tested parameters AUC's with 0.5 AUC.

diagnostic value of the presence of M-CSF in various diagnostic panels with established tumor markers was evaluated $(6,23,28,31,36)$. Diagnostic specificity (SP) reached the highest values for both cytokines and MMP-9 (95.2\%). Review of the existing literature, indicated that similar results have been obtained by other investigators regarding the course of ovarian cancer $(81.4-100 \%)(21,28$, $35)$. It should be underlined, that among the examined factors MMP-7 showed comparable or higher values of PPV and NPV compared to those presented by HE4, while M-CSF and MMP-9 presented the highest values of PPV in the whole group studied $(\sim 84.5 \%)$. In the present study, the combination of CA125 with MMP-7 had undoubtedly the highest NPV value, $\sim 98 \%$. These findings as well as the results on TIMP-1 are partially in accordance with our previous publications (19, 28) probably as a result of differences in the composition of control groups. Unfortunately, we could not compare our data regarding the poor diagnostic utility of MMP-2 and TIMP-2 in ovarian cancer with the results of other researchers due to a lack of publications on the subject, although their diagnostic power was demonstrated in breast (32) or pancreatic malignancies (27).

In summary, to the best of our knowledge, the current study is the first to evaluate the diagnostic utility of preoperative plasma levels of 9 carefully selected markers: cytokines, MMPs and TIMPs independently and in combination with CA125 or HE4, based on the area under the ROC curve analysis. The strength of the current results lies in the fact that the study groups (OC patients and control BOT group) were homogeneous, only serous and endometrioid sub-types of epithelial ovarian tumors were enrolled, and all participants were postmenopausal. Statistical analysis showed that HE4 was superior to CA125 in discriminating between OC and control group. The results of this study also suggest that combining VEGF, MMP-7 or MMP-9 in the diagnostic panels with HE4 and/or CA125 measurements might minimize the rate of misdiagnosis and improve the diagnostic power of both commonly used tumor markers. 


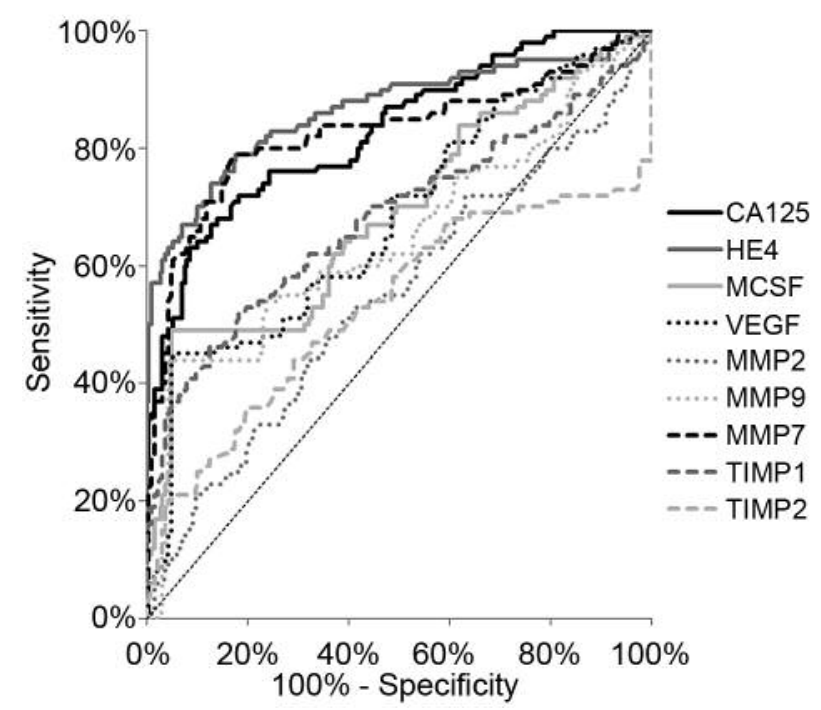

Figure 1. Areas under the ROC curve (AUC) for selected cytokines (M-CSF, VEGF) MMPs (MMP-2, MMP-7, MMP-9), TIMPs (TIMP-1, TIMP-2), CA125 and HE4 in ovarian cancer (OC) patients.

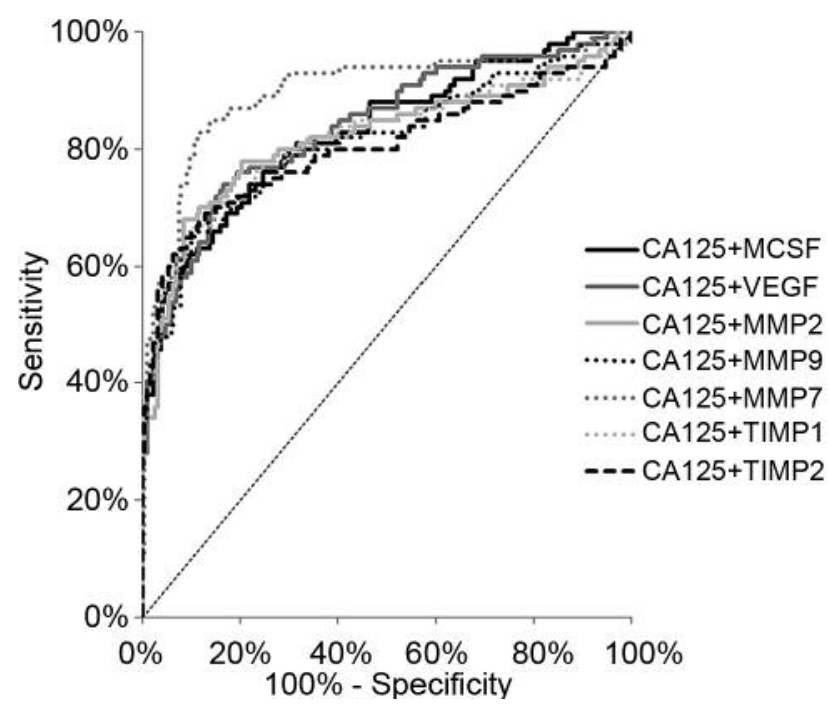

Figure 2. Areas under the ROC curve (AUC) for selected cytokines (M-CSF, VEGF) MMPs (MMP-2, MMP-7, MMP-9), TIMPs (TIMP-1, TIMP-2), combined with CA125 in ovarian cancer (OC) patients.

\section{Conflicts of Interest}

The Authors declare that they have no competing interests.

\section{Authors' Contributions}

GEB conceived the study, performed the immunoassays, conducted the statistical analysis and drafted the manuscript; BP performed the

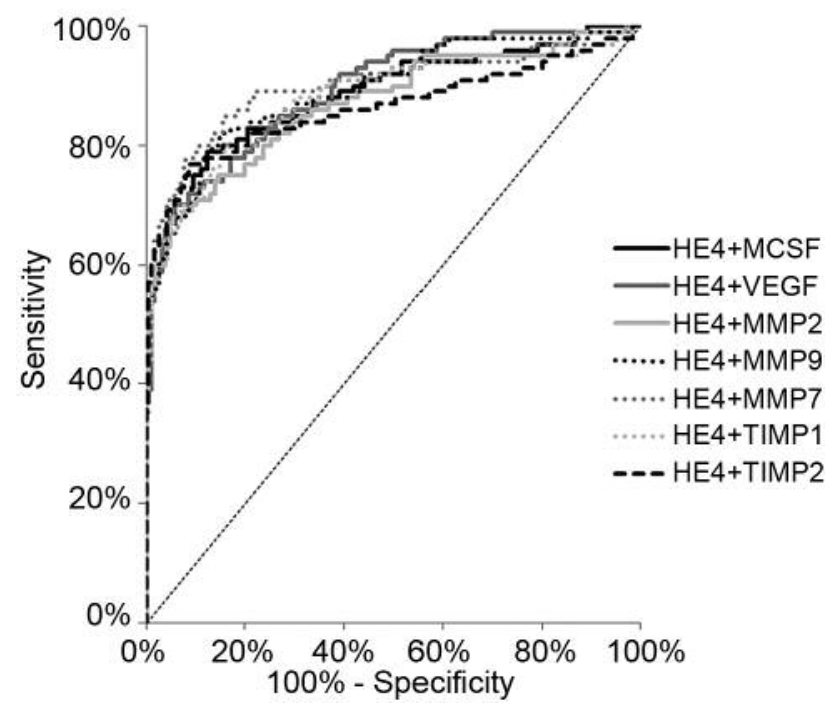

Figure 3. Areas under the ROC curve (AUC) for selected cytokines ( $M$-CSF, VEGF) MMPs (MMP-2, MMP-7, MMP-9), TIMPs (TIMP-1, TIMP-2), combined with HE4 in ovarian cancer (OC) patients.

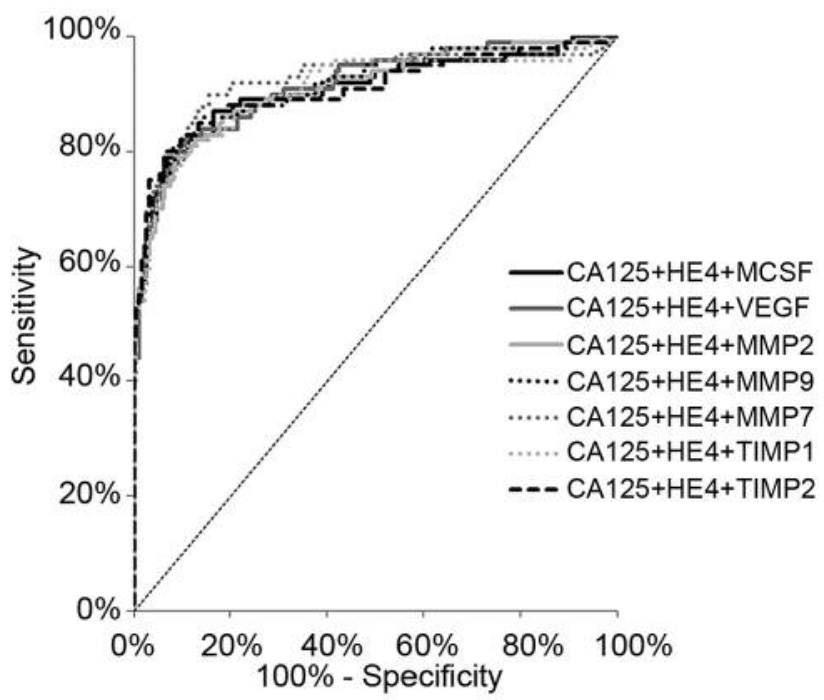

Figure 4. Areas under the ROC curve (AUC) for selected cytokines (M-CSF, VEGF) MMPs (MMP-2, MMP-7, MMP-9), TIMPs (TIMP-1, TIMP-2), combined with CA125 and HE4 in ovarian cancer (OC) patients.

immunoassays and assisted in drafting the manuscript; EG conducted data acquisition and participated in sequence alignment; MZ performed the immunoassays; JO participated in data interpretation; MS participated in data interpretation; MD participated in the design and coordination of the study; SŁ participated in the design and coordination of the study, data interpretation and assisted in drafting the manuscript. All Authors have read and approved the final manuscript. 


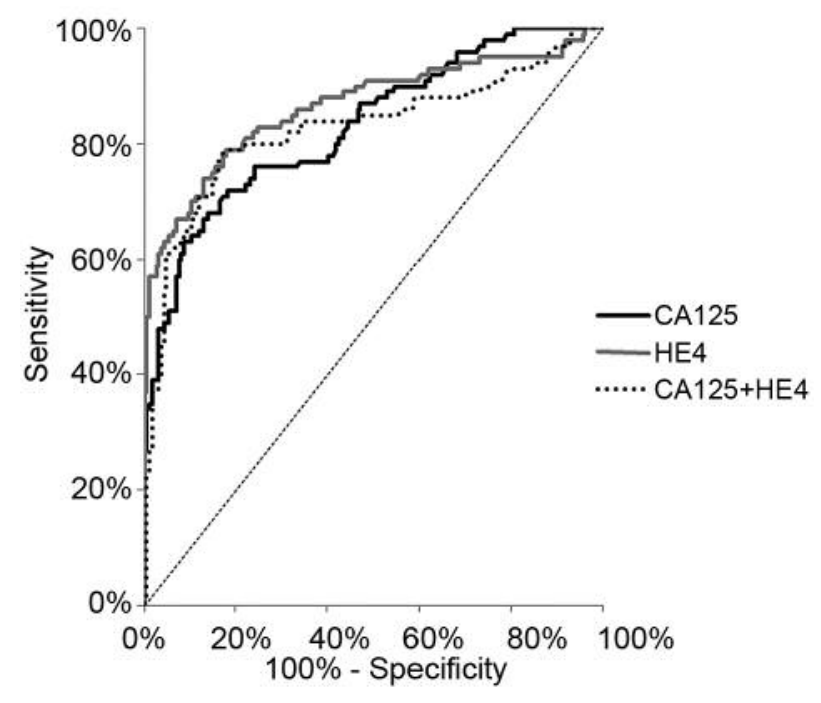

Figure 5. Areas under the ROC curve (AUC) for CA125 and HE4 in ovarian cancer $(O C)$ patients.

\section{Acknowledgements}

This research was financed by a Grant for Scientific Research (nr N N407 530738) in the years 2010-2014 from the Polish Ministry of Science and Higher Education.

\section{References}

1 Jemal A, Bray F, Center MM, Ferlay J, Ward E and Forman D: Global cancer statistics. CA Cancer J Clin 61(2): 69-90, 2011. PMID: 21296855. DOI: 10.3322/caac. 20107

2 Siegel R, Ward E, Brawley O and Jemal A: Cancer statistics: the impact of eliminating socioeconomic and racial disparities on premature cancer deaths. CA Cancer J Clin 61(4): 212-236, 2011. PMID: 21685461. DOI: 10.3322/caac.20121

3 Erickson BK, Conner MG and Landen $\mathrm{CN}$ : The role of the fallopian tube in the origin of ovarian cancer. Am J Obstet Gynecol 209(5): 409-414, 2013. PMID: 23583217. DOI: 10.1016/j.ajog.2013.04.019

4 Molina R, Escudero JM, Auge JM, Filella X, Foj L, Torne A, Lejarcegui $\mathrm{J}$ and Pahisa J: HE4 a novel tumour marker for ovarian cancer: comparison with CA 125 and ROMA algorithm in patients with gynaecological diseases. Tumor Biol 32(6): 1087-1095, 2011. PMID: 21863264. DOI: 10.1007/s13277-0110204-3.

5 Schummer M, Drescher C, Forrest R, Gough S, Thorpe J, Hellstrom I, Hellström KE and Urban N: Evaluation of ovarian cancer remission markers HE4, MMP7 and mesothelin by comparison to the established marker CA125. Gynecol Oncol 25(1): 65-69, 2012. PMID: 22155417. DOI: 10.1016/j.ygyno.2011.11.050

6 Ławicki S, Gacuta-Szumarska E, Będkowska GE and Szmitkowski M: Hematopoietic cytokines as tumor markers in gynecological malignancies. A multivariate analysis in epithelial ovarian cancer patients. Growth Factors 30(6): 357-366, 2012. PMID: 22988839. DOI: 10.3109/08977194.2012.724407
7 Candido dos Reis FJ, Moreira de Andrade J and Bighetti S: CA 125 and vascular endothelial growth factor in the differential diagnosis of epithelial ovarian tumors. Gynecol Obstet Invest 54(3): 132-136, 2002. PMID: 12571433. DOI: 10.1159/000067877

8 Chan KKL, Chen CA, Nam JH, Ochiai K, Wilailak S, Choon AT, Sabaratnam S, Hebbar S, Sickan J, Schodin BA and Sumpaico WW: The use of HE4 in the prediction of ovarian cancer in Asian women with a pelvic mass. Gynecol Oncol 128(2): 239-244, 2013. PMID: 23063998. DOI: 10.1016/ j.ygyno.2012.09.034

9 Behrens P, Rothe M, Florin A, Wellman A and Wernert N: Invasive properties of serous human epithelial ovarian tumors are related to Ets-1, MMP-1 and MMP-9 expression. Int J Mol Med 8(2): 149-154, 2001. PMID: 11445865.

$10 \mathrm{Hu} \mathrm{X,} \mathrm{Li} \mathrm{D,} \mathrm{Zhang} \mathrm{W,} \mathrm{Zhou} \mathrm{J,} \mathrm{Tang} \mathrm{B} \mathrm{and} \mathrm{Li} \mathrm{L:} \mathrm{Matrix}$ metalloproteinase- 9 expression correlates with prognosis and involved in ovarian cancer cells invasion. Arch Gynecol Obstet 286(6): 1537-1543, 2012. PMID: 22832979. DOI: 10.1007/ s00404-012-2456-6

11 Niedworok C, vom Dorp F, Tschirdewahn S, Rübben H, Reis H, Szucs $M$ and Szarvas T: Validation of the diagnostic and prognostic relevance of serum MMP-7 levels in renal cell cancer by using a novel automated fluorescent immunoassay method. Int Urol Nephrol 48(3): 355-361, 2016. PMID: 26725072. DOI: $10.1007 / \mathrm{s} 11255-015-1185-8$

12 Christensen IJ, Brünner N, Dowell B, Davis G, Nielsen HJ, Newstead G and King D: Plasma TIMP-1 and CEA as markers for detection of primary colorectal cancer: A prospective validation study including symptomatic and non-symptomatic individuals. Anticancer Res 35(9): 4935-4941, 2015. PMID: 26254391.

13 Karlsen MA, Sandhu N, Hegdall C, Christensen IJ, Nedergaard L, Lundvall L, Engelholm SA, Pedersen AT, Hartwell D, Lydolph M, Laursen IA and Høgdall EV: Evaluation of HE4, CA125, risk of ovarian malignancy algorithm (ROMA) and risk of malignancy index (RMI) as diagnostic tools of epithelial ovarian cancer in patients with a pelvic mass. Gynecol Oncol 127(2): 397-383, 2012. PMID: 22835718. DOI: 10.1016/j.ygyno.2012.07.106

14 Jacob F, Meier M, Caduff R, Goldstein D, Pochechueva T, Hacker N, Fink D and Heinzelmann-Schwarz V: No benefit from combining HE4 and CA125 as ovarian markers in clinical setting. Gynecol Oncol 121(3): 487-491, 2011. PMID: 21420727. DOI: $10.1016 /$ j.ygyno.2011.02.022

15 Zheng Li, Qu JY and He F: The diagnosis and pathological value of combined detection of HE4 and CA125 for patients with ovarian cancer. Open Med 11(1): 125-132, 2016. PMID: 28352789. DOI: 10.1515/med-2016-0024

16 Park Y, Lee JH, Hong DJ, Lee EY and Kim HS: Diagnostic performances of HE4 and CA 125 for the detection of ovarian cancer from patients with various gynecologic and nongynecologic diseases. Clin Biochem 44(10-11): 884-888, 2011. PMID: 21549107. DOI: 10.1016/j.clibiochem.2011.04.011

17 Partheen K, Kristjansdottir B and Sundfeldt K: Evaluation of ovarian cancer biomarkers HE4 and CA-125 in women presenting with a suspicious cystic ovarian mass. J Gynecol Oncol 22(4): 244-252, 2011. PMID: 22247801. DOI: 10.3802/ jgo.2011.22.4.244

18 Kristjansdottir B, Levan K, Partheen K and Sundfeldt K: Diagnostic performance of the biomarkers HE4 and CA125 in type I and type II epithelial ovarian cancer. Gynecol Oncol 131(1): 52-58, 2013. PMID: 23891789. DOI: 10.1016/j.ygyno.2013.07 
19 Będkowska GE, Gacuta E, Zajkowska M, Głażewska EK, Osada J, Szmitkowski M, Chrostek L, Dąbrowska M and Ławicki S: Plasma levels of MMP-7 and TIMP-1 in laboratory diagnostics and differentiation of selected histological types of epithelial ovarian cancers. J Ovarian Res 10(1): 39, 2017. PMID: 28662671. DOI: 10.1186/s13048-017-0338-z

20 Ławicki S, Będkowska GE, Gacuta-Szumarska E and Szmitkowski M: The plasma concentration of VEGF, HE4 and CA125 as a new biomarkers panel in different stages and subtypes of epithelial ovarian tumors. J Ovarian Res 6(1): 45-55, 2013. PMID: 23819707. DOI: 10.1186/1757-2215-6-45

21 Dalal V, Kumar R, Kumar S, Sharma A, Kumar L, Sharma JB, Roy KK, Singh N and Vanamail P: Biomarker potential of IL-6 and VEGF-A in ascitic fluid of epithelial ovarian cancer patients. Clin Chim Acta 482: 27-32, 2018. PMID: 29572186. DOI: 10.1016/j.cca.2018.03.019

22 Coticchia CM, Curatolo AS, Zurakowski D, Yang J, Daniels KE, Matulonis UA and Moses MA: Urinary MMP-2 and MMP-9 predict the presence of ovarian cancer in women with normal CA125 levels. Gynecol Oncol 123(2): 295-300, 2011. PMID: 21889192. DOI: 10.1016/j.ygyno.2011.07.034.

23 Zajkowska M, Głażewska EK, Będkowska GE, Chorąży P, Szmitkowski M and Ławicki S: Diagnostic power of vascular endothelial growth factor and macrophage colony- stimulating factor in breast cancer patients based on ROC analysis. Mediators Inflamm 2016: 5962946, 2016. PMID: 27445439. DOI: $10.1155 / 2016 / 5962946$.

24 Ławicki S, Głażewska EK, Sobolewska M, Będkowska GE and Szmitkowski M: Plasma levels and diagnostic utility of macrophage colony-stimulating factor, matrix metalloproteinase-9, and tissue inhibitor of metalloproteinases- 1 as a new biomarkers of breast cancer. Ann Lab Med 36(3): 223-229, 2016. PMID: 26915610. DOI: 10.3343/alm.2016.36.3.223.

$25 \mathrm{Wu}$ J, Liu X and Wang Y: Predictive value of preoperative serum CCL2, CCL18, and VEGF for the patients with gastric cancer. BMC Clin Pathol 13: 15, 2013. PMID: 23697837. DOI: 10.1186/1472-6890-13-15

26 Määttä M, Talvensaari-Mattila A, Turpeenniemi-Hujanen T and Santala M: Matrix metalloproteinase-2 (MMP-2) and -9 (MMP9) and their tissue inhibitors (TIMP-1 and TIMP-2) in differential diagnosis between low malignant potential (LMP) and malignant ovarian tumours. Anticancer Res 27(4C): 27532758, 2007. PMID: 17695443.

27 Roy R, Zurakowski D, Wischhusen J, Frauenhoffer C, Hooshmand S, Kulke M and Moses MA: Urinary TIMP-1 and MMP-2 levels detect the presence of pancreatic malignancies. $\mathrm{Br}$ J Cancer 111(9): 1772-1779, 2014. PMID: 25137018. DOI: $10.1038 / \mathrm{bjc} .2014 .462$
28 Będkowska GE, Ławicki S, Gacuta E, Pawłowski $\mathrm{P}$ and Szmitkowski M: M-CSF in a new biomarker panel with HE4 and CA125 in the diagnostics of epithelial ovarian cancer patients. J Ovarian Res 8: 27, 2015. PMID: 25935153. DOI: 10.1186/s13048015-0153-3.

29 Ławicki S, Będkowska GE, Gacuta-Szumarska E and Szmitkowski M: Hematopoietic cytokines as tumor markers in gynecological malignancies: A multivariate analysis with ROC curve in endometrial cancer patients. Growth Factors 30(1): 29-36, 2012. PMID: 22010785. DOI: 10.31109/08977194.2011.627332.

30 Ławicki S, Szmitkowski M and Wojtukiewicz M: The pretreatment plasma level and diagnostic utility of M-CSF in benign breast tumor and breast cancer patients. Clin Chim Acta 371(1-2): 112116, 2006. PMID: 16631152. DOI: 10.1016/j.cca.2006.02.033

31 Ławicki S, Będkowska GE and Szmitkowski M: VEGF, M-CSF and CA15-3 as a new tumor marker panel in breast malignances: a multivariate analysis with ROC curve. Growth Factors 31(3): 98-105, 2013. PMID: 23688065. DOI: 10.3109/08977194. 2013.797900

32 Ławicki S, Zajkowska M, Głażewska EK, Bęfkowska GE and Szmitkowski M: Plasma levels and diagnostic utility of M-CSF, MMP-2 and its inhibitor TIMP-2 in the diagnostics of breast cancer patients. Clin Lab 62(9): 1661-1669, 2016. PMID: 28164586. DOI: 10.7754/Clin.Lab.2106.160118

33 Zohny SF and Fayed ST: Clinical utility of circulating matrix metalloproteinase-7 (MMP-7), CC chemokine ligand 18 (CCL 18) and $\mathrm{CC}$ chemokine ligand 11 (CCL 11) as a marker for diagnosis of epithelial ovarian cancer. Med Oncol 27(4): 1246-1253, 2010. PMID: 19937162. DOI: 10.1007/s12032-009-9366-X

34 Zhang W, Yang HC, Wang Q, Yang ZJ, Chen H, Wang SM, Pan ZM, Tang BJ, Li QQ and Li L: Clinical value of combined detection of serum matrix metalloproteinase-9, heparanase, and cathepsin for determining ovarian cancer invasion and metastasis. Anticancer Res 31(10): 3423-3428, 2011. PMID: 21965756.

35 Zhang W, Hu XX, Yang XZ, Wang Q, Cheng H, Wang SM, Hu YL, Yang ZJ and Li L: Combined detection of serum matrix metalloproteinase 9, acetyl heparinase and cathepsin L in diagnosis of ovarian cancer. Chin J Cancer Res 24(1): 67-71, 2012. PMID: 23359763. DOI: 10.1007/s11670-012-0067-1

36 Ławicki S, Będkowska GE, Gacuta-Szumarska E, Knapp P and Szmitkowski M: Pretreatment plasma levels and diagnostic utility of hematopoietic cytokines in cervical cancer or cervical intraepithelial neoplasia patients. Folia Histochem Cytobiol 50(2): 213-219, 2012. PMID: 22763962.

Received March 7, 2019 Revised April 4, 2019 Accepted April 8, 2019 